\title{
MATLAB SIMULINK Model for Flyback Inverter with Active Clamp Technique
}

\author{
N.Kamalakannan ${ }^{1}$, A.Arulvizhi ${ }^{2}$, C.Kirthana ${ }^{3}$ \\ Associate Professor \&Head/EEE, CK College of Engg \& Tech, Cuddalore, India ${ }^{1}$ \\ Assistant Professor/EEE, CK College of Engg \& Tech, Cuddalore, India ${ }^{2}$ \\ Assistant Professor/EEE, CK College of Engg \& Tech, Cuddalore, India ${ }^{3}$
}

\begin{abstract}
The interleaved flyback inverter is the proposed system.. Two flyback inverters are connected and the control strategy used is the active clamp technique. This technique reduces the voltage spikes across the main switch during resonance, and the switching losses are reduced along with voltage stress. The system is modified as an energy storage application. The efficiency is improved and The simulations are done using MATLAB .The explanations theories and results are discussed.
\end{abstract}

Keywords: ILFI, induction motor drive, active clamp, energy storage.

\section{INTRODUCTION}

The drive system plays an important role in the modern industries. The most significant drive system in industries are the induction motor drive system.Based on their application and requirements they are classified into single phase and three phase AC induction motor.Washing machine, furnace, conveyor,pump, wind tunnels are the areas where they are used.speed variations, heavy load inertial starting with higher starting torque are the significant applications of induction motor. Desired output at maximum efficiency with low losses are produced by these induction motors. Voltage variations, unbalance,motor load,THD and power factor are the factors affecting motor efficiency.this paper deals with ILFI[1].(interleaved flyback inverter) fed induction motor with space vector modulation technique.. and active clamp technique is implemented[2]. The clamp circuit is used to reduce the switching loss and the voltage spikes across the main switch.

Operation at increased power levels are obtained by using interleaving concept. The RMS current in the input capacitor is reduced. this results in the reduced number of capacitors and less expensive. primary and secondary transformer winding peak currents are reduced.the transientresponse is improved and the electromagnetic interference is improved as a result of interleaving concept.The decoupling capacitor ,first phase converter,second phase converter,unfolding bridge,C-L filter are the components of the ILFI converter.a $120 \mathrm{~Hz}$ harmonic frequency is removed by using the decoupling capacitor. The main switches are present in the each phase of the flyback converteralong with clamp citcuit, transformer and diodes. The voltage across the main switch is reduced by the clamp circuit. The configuration and structure of the interleaved flyback inverter is described below along with it's modes of operation. The Energy storage has become an important application nowadays, The energy storage is an old process such that energy during the creation of the universe has been stored in sun, moon etc but now humans use them directly through solar and by changing them into electricity.
This process of energy storage has been implemented using devices which serve as an accumulator. In this paper interleaved flyback inverter has been modified for enery storage application. The interleaved flyback inverter is simulated with induction motor drive and the system is simulated for energy storage application using MATLAB . The calculations are presented for switching loss, voltage stress and efficiency is improved.

\section{ILFI CONFIGURATION}

The interleaved flyback inverter has two flyback inverters connected parallel and the technique used is the active clamp technique. This technique is used to reduce the switching loss of the switches.

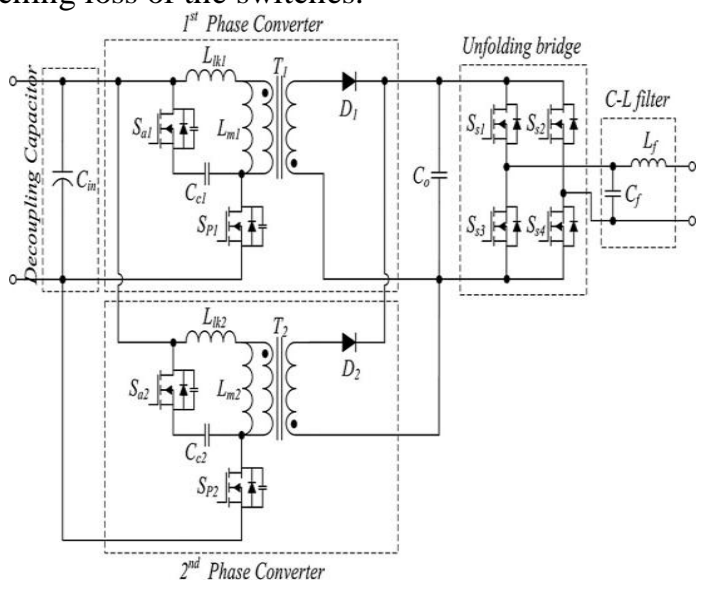

Fig 1 ILFI structure

the isolation between the PV module and the grid line is provided by the isolation transformer.boosting of voltage also takes place.the connection between the AC power provided through transformer grid line is employed by unfolding bridge.

\section{MODES OF OPERATION}

The single phase converter without the active clamp circuit is activated by the interleaved flyback inverter using the phase control method and the active clamp control method. 


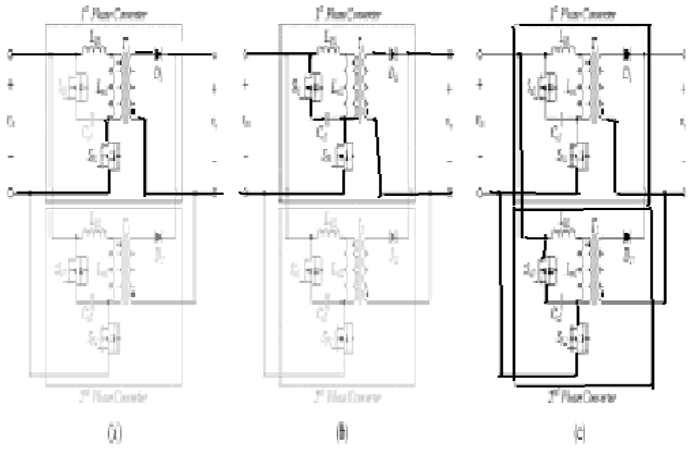

Fig 2 modes of operation

MODE1

All the other switches are turned off except the switch Sp1.this energizes the leakage and magnetic inductance.the current flow is through the magnetic flux,this forward biases diode D1. the energy is delivered to the load through the output capacitor MODE2

In this mode the energization of leakage and magnetic inductance takes place with $\mathrm{Sp} 1$ and Sa1 turned on.the enegy is transferred to the load through the output capacitor.

MODE3

In this mode both the phases are turned on.Sp1,Sp2,Sa1,Sa2 are turned on.the capacitor delivers energy to the load.

\section{ACTIVE CLAMP CONTROL METHOD}

Solar irradiance and atmospheric temperature are the two parameters influencing the output power of the PV module .the ILFI efficiency has to be improved which depends on the irradiance values of the weather conditions the active clamp circuit comprises of the switch $\mathrm{Sa} 1$ and a capacitor in each phase of the converter.this helps in reducing the voltage spikes across the main switch.thus when each phase of the ILFI is controlled the the losses are minimized.when Sp1 is turned off the voltage is formed by Sp1 votage without clamp circuit sum of input voltage Vin through PV module feedback voltage,spike voltage Vsp1.

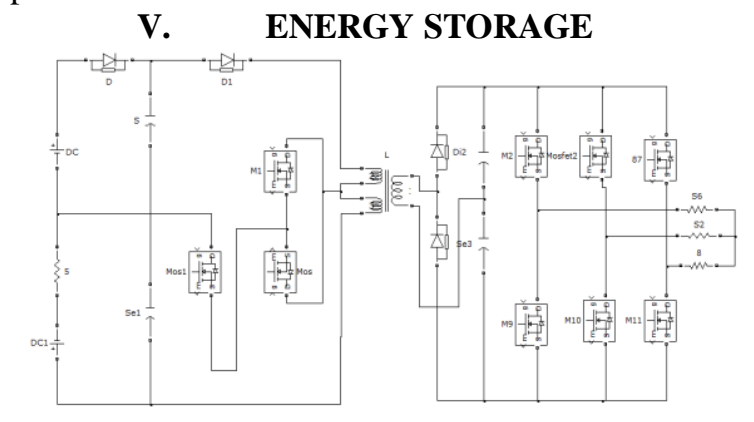

Fig 3 energy storage

The energy storage consists of the interleaved flyback inverter with three switches which act as the main switch and there are two DC supplies as the input source when one of the source is assigned a value the other is turned off and when the other switch has input voltage this switch switch which was turned on before will be turned off.

\section{SIMULATION RESULTS}

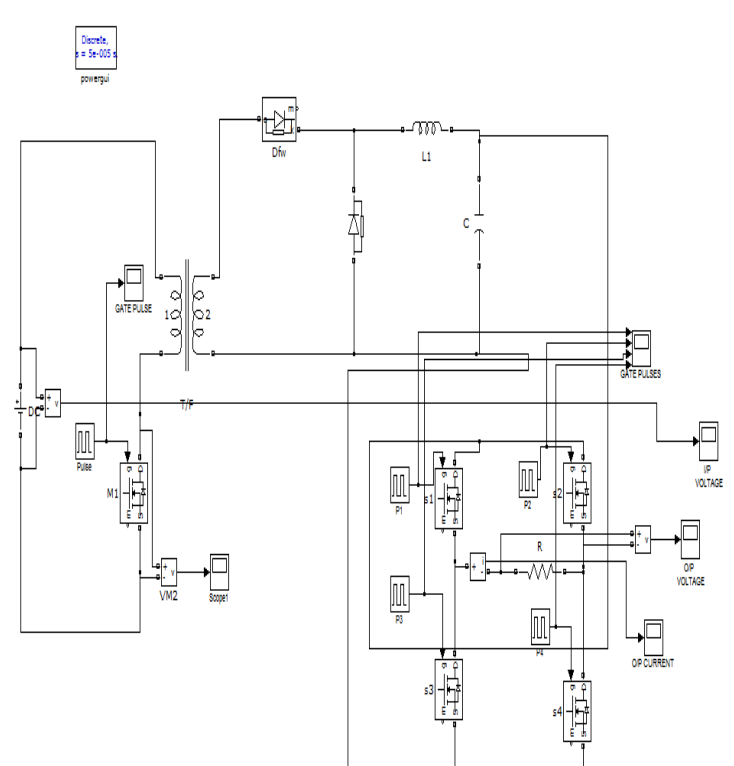

Fig 4 simulink model of existing system
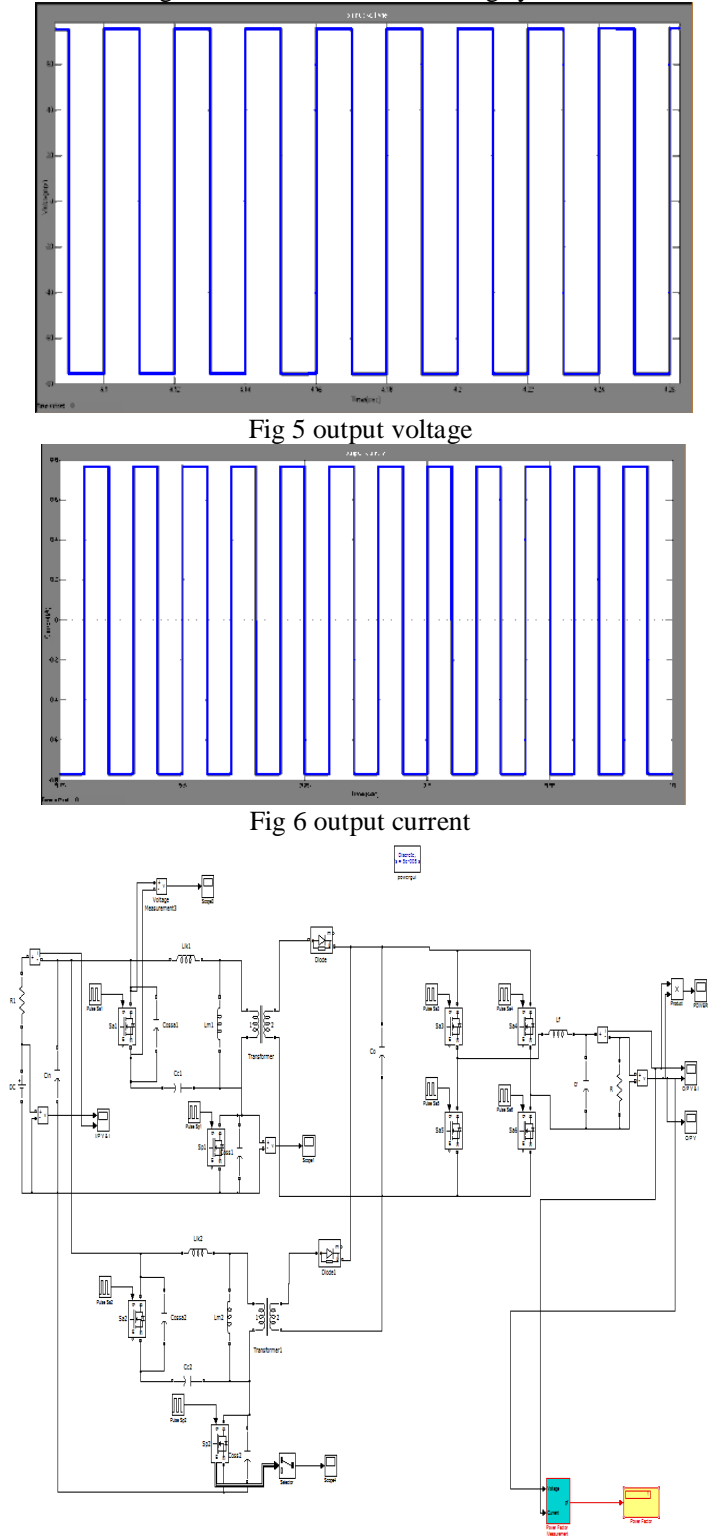

Fig 7 simulink model of ILFI R load 


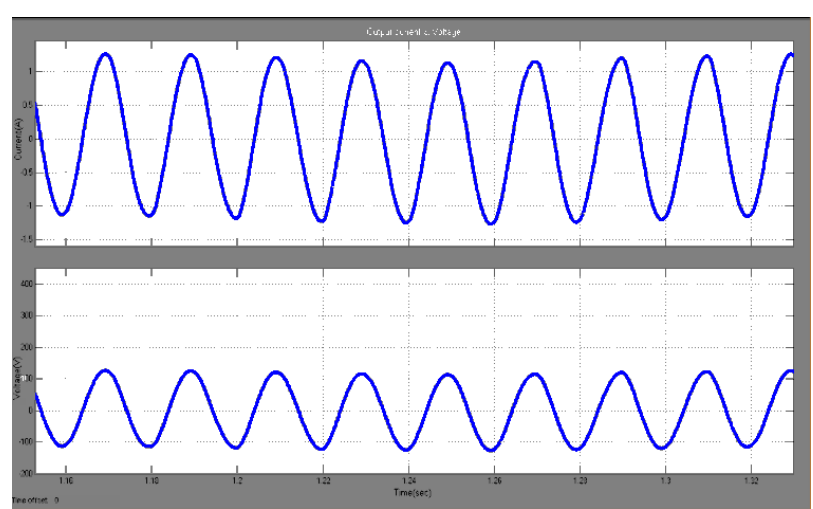

Fig 8 output voltage and output current

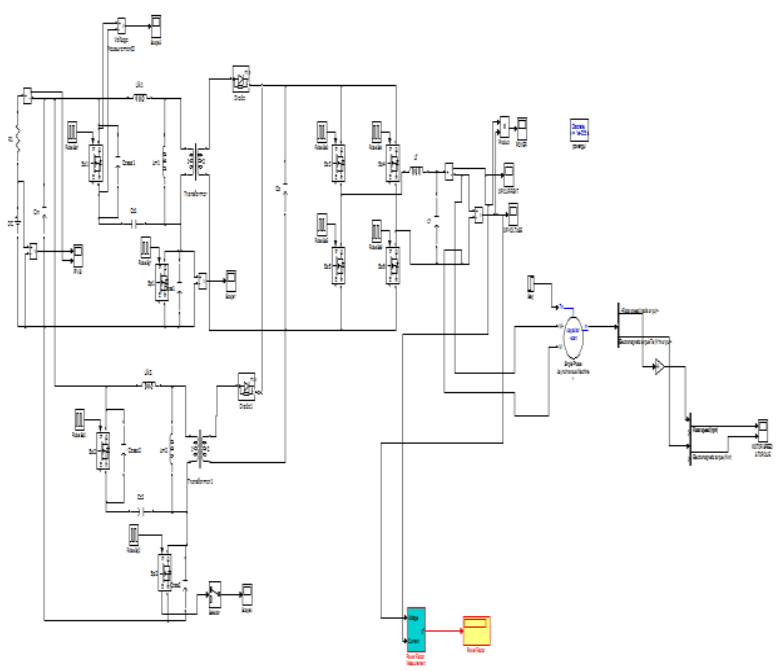

Fig 9 simulink model of ILFI motor load

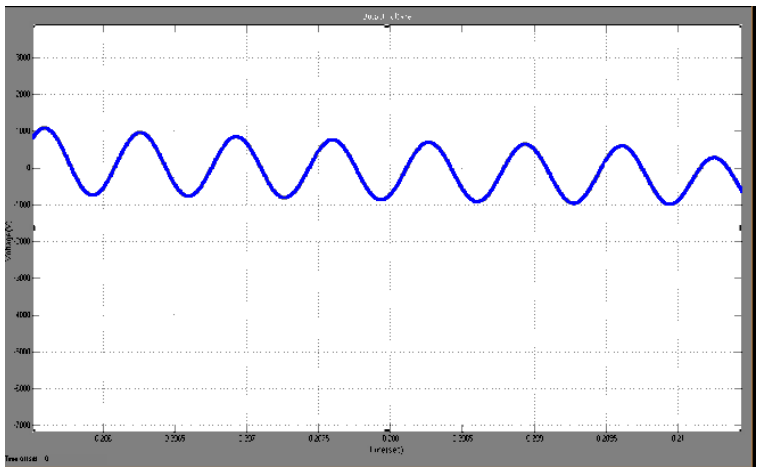

Fig 10 output voltage

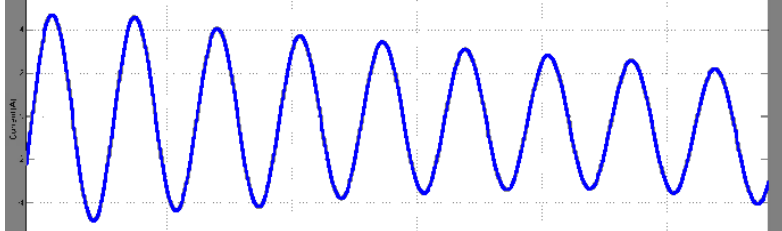

Fig 11 output current 
INTERNATIONAL JOURNAL OF INNOVATIVE RESEARCH IN ELECTRICAL, ELECTRONICS, INSTRUMENTATION AND CONTROL ENGINEERING Vol. 3, Issue 3, March 2015

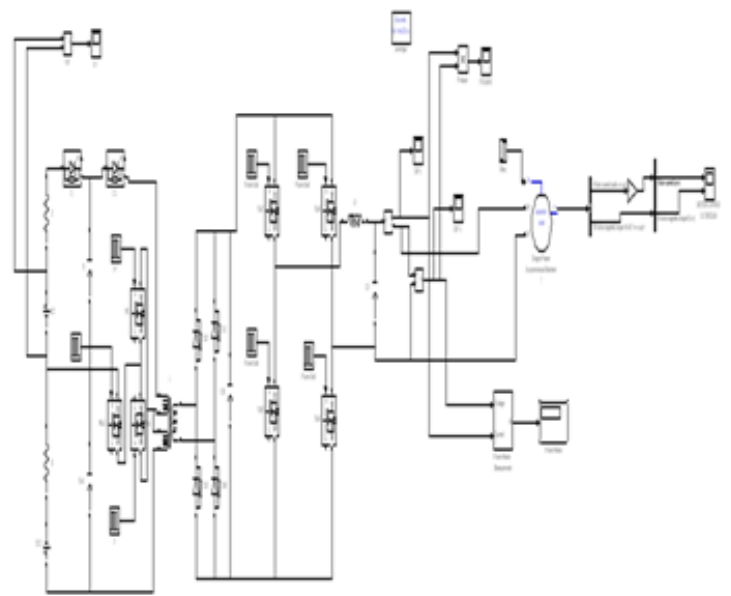

Fig 16 simulink model with motor load

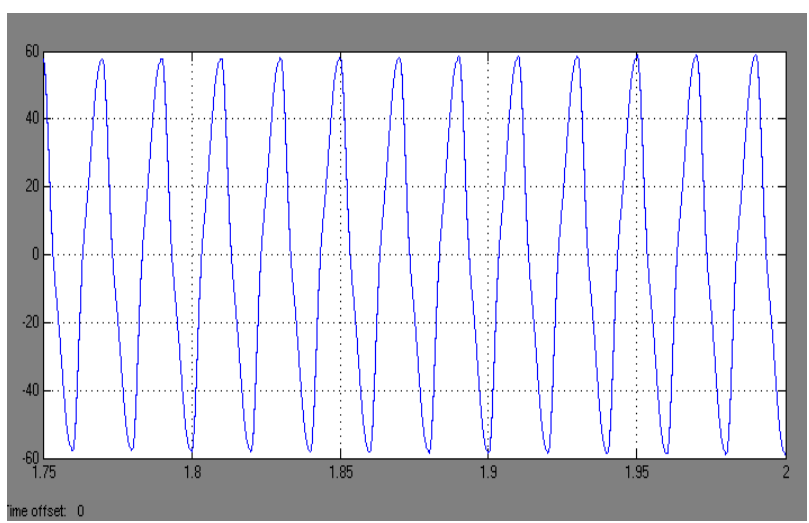

Fig 17 output voltage

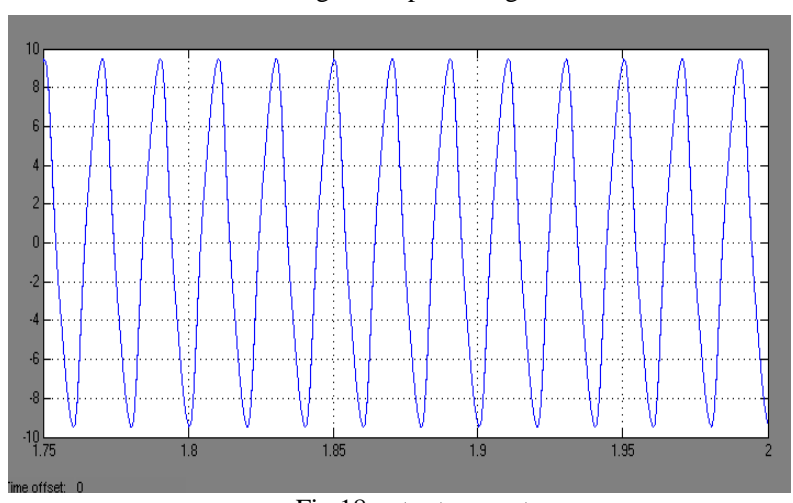

Fig 18 output current

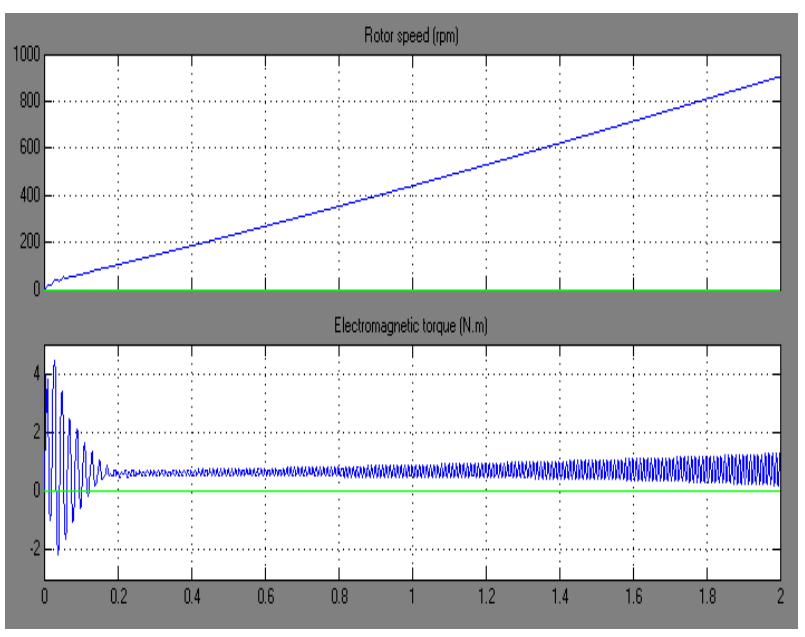

Fig 19 speed torque curve
VII. CALCULATION

CONVENTIONAL SYSTEM

Stress :S=F/Vo

$=50 / 70$

$=0.714$

$\mathrm{S}=0.714$

Efficiency

$\mathrm{E}=2(1-\mathrm{D}) * \mathrm{~V} ; \mathrm{V}=$ output-input

$=70-30$

$=40$

$\mathrm{E}=2(1-0.5) * 40$

$\mathrm{E}=40 \%$

PROPOSED SYSTEM

Stress: $\mathrm{s}=\mathrm{F} / \mathrm{Vo}$

$=50 / 110$

$=0.45$

Efficiency

$\mathrm{E}=2(1-\mathrm{D}) * \mathrm{~V}$

$\mathrm{V}=$ output-input

$=110-20$

$=90$

$\mathrm{E}=2(1-0.5) * 90$

$\mathrm{E}=90 \%$

\section{SWITCHING LOSS}

$=\mathrm{C} * \mathrm{Vds} * \mathrm{Fsw}$

$=400 * 10^{\wedge}-12 * 55 * 70000$

$=0.00154$

\section{HARDWARE RESULTS}

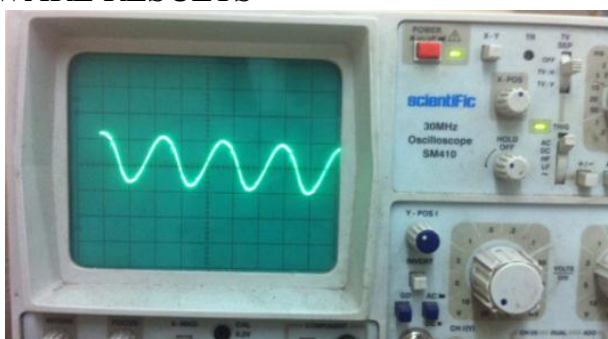

Fig 20. Output voltage

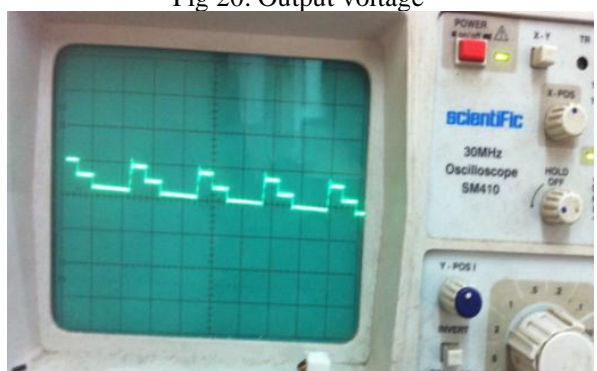

Fig 21 inverter pulse

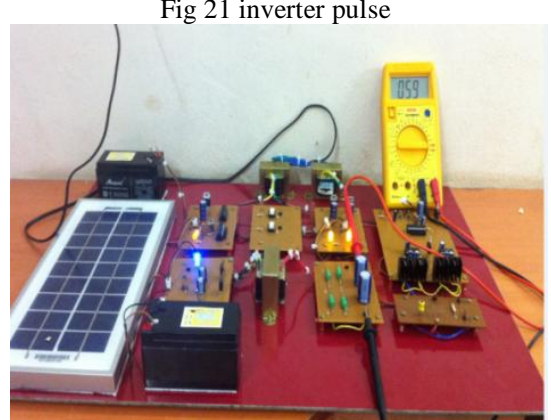

Fig 22 hardware proptotype with solar panel VIII. 
Thus the switching losses and the voltage stress are reduced and the efficiency is improved compared to the existing system. The simulations are done using MATLAB and the results are presented The system has been modified for energy storage application and simulated with induction motor drive as the load.

\section{REFERENCES}

[1] C. T. Choi, C. K. Li, and S. K. Kok, "Control of an active clamp discontinuous conduction mode flyback converter," in Proc. IEEE Power Electron.Drive Syst. Conf., 1999, vol. 2, pp. 1120-1123.

[2] R. Watson, F. C. Lee, and G. Hua, "Utilization of an active-clamp circuit to achieve soft switching ," IEEE Trans. PowerElectron., vol. 11, no. 1, pp. 162-169, Jan. 1996.

[3] Y.-K. Lo and J.-Y. Lin, "Active-clamping ZVS flyback converter employing two transformers," IEEE Trans. Power Electron., vol. 22, no. 6,pp. 2416-2423, Nov. 2007.

[4] G.-B. Koo and M.-J. Youn, "A new zero voltage switching active clamp flyback converter," in Proc. IEEE Power Electron. Spec. Conf., 2004,pp. 508-510.

[5] P. Alou, A. Bakkali, I. Barbero, J. A. Cobos, and M. Rascon, "A low power topology derived from flyback with active clamp based on a very simple transformer," in Proc. IEEE Appl. Power Electron. Conf., 2006,pp. 627-632.

[6] E. H. Wittenbreder, "Zero voltage switching pulse with modulated power converters,” U.S. Patent 5402329, Mar. 1995.

[7] D. A. Cross, "Clamped continuous flyback power converter," U.S. Patent5570278, Oct. 1996.

[8] T. M. Chen and C.-T. M. Chen and C.-L. Chen, "Analysis and design of asymmetrical half bridge Flyback converter," IEE Proc.Electr. Power Appl., vol. 149, no. 6,pp. 433-440, Nov. 2002.

[9] D. Fu, F. C. Lee, Y. Qiu, and F. Wang, "A novel high-powerdensity three-level LCC resonant converter with constant-po A. C. Kyritsis, E. C. Tatakis, and N. P. Papanikolaou, "Optimum design of the -connected photovoltaic systems," IEEE Trans. Energy Convers., vol. 23, no. 1, pp. 281-293, Mar. 2008.

[10] N. Kasa, T. Iida, and L. Chen, "Flyback inverter controlled by sensorless current MPPT for photovoltaic power system," IEEE Trans. Ind. Electron., vol. 52, no. 4, pp. 1145-1152, Aug. 2005.

[11] J. Zhang, X. Huang, X. Wu, and Z. Qian, "A high efficiency flyback converter with new active clamp technique," IEEE Trans. Power Electron., vol. 25, no. 7, p. 1775-1785, Jul. 2010

\section{BIOGRAPHIES}

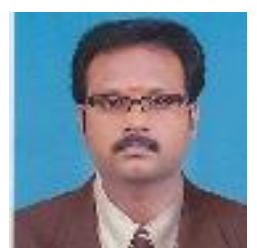

Mr.N.Kamalakannan was born on $11^{\text {th }}$ November 1979 in Tamilnadu, India. He received his Electrical \& Electronics Engineering degree from Annamalai Universitym Chidambaram \& M.E degree from Anna University, Chennai. He is currently working as Associate Professor \& Head in department of Electrical \& Electronics Engg. at CK College of Engineering \& Technology, Cuddalore.
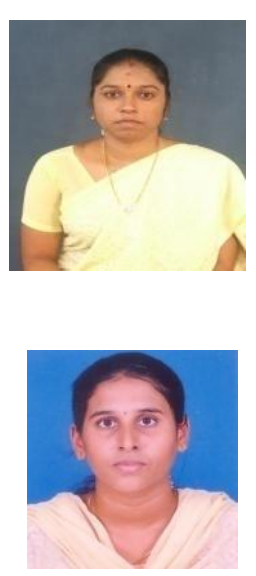

Mrs A.Arulvizhi is currently working as Assistant Professor in CK College of Engineering \& Technology. She has over eleven years of teaching experience. She completed her post graduation in Power Systems from Annamalai University and is currently pursuing her doctorate in the field of power system.

C.Kirthana is currently working as Assistant Professor in CK college of engineering \& technology. She completed her post graduation in Power Electronics \& Drives in 2014 from Jeppiaar Engineering college,Chennai .Her area of interest includes Power electronic devices. 